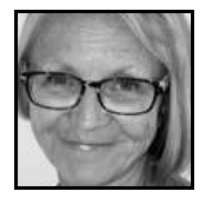

\title{
Commentary Living Your Values in Your Practice
}

Judith McBride

\section{ABSTRACT}

In this interview, Judith McBride describes how she first became interested in teacher research as a graduate student and how a summer school course with influential educator Jack Whitehead propelled her through a "huge transformation" that changed the way she taught and the way she thought about teaching. She was involved in teacher research during her career as a high school teacher and was instrumental in guiding other teachers in action research and narrative inquiry. Now retired from teaching, she continues to contribute to this field in a variety of projects and shares her advice to teachers who wish to research their own practice.

\section{Can you describe how you became involved in teacher research?}

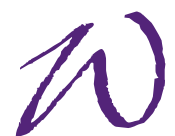

hen I was doing graduate work I had a mentor here at McGill and she was a graduate student working as a T.A. in a class that I was taking and she had been a classroom teacher. She was then doing her doctoral studies and I kind of fell in love with her work because she had been working with gifted kids using inquiry, which was all new to me. She said, "Well, you could be doing research on your practice," and I said, "Oh!" It never occurred to me that I could be doing something like that. And so, I was taken under her wing for a long time. She then left to teach at Bishop's University.

She later called me to say that she had a guest professor coming from the U.K. that summer and I was introduced to the work of Jack Whitehead and that was it. I just knew that teacher research was what I had to do for the rest of my teacher life: that meant 
to be looking for problems and trying to find solutions, not waiting for things to wash over me, not listening to the whining in the staffroom anymore, but being proactive. The most important part of it was learning to work through my values by being very clear about what I cared about in education, to be always focused on working through my values, looking at the contradictions and ways to overcome the problems that came in practice. It just became a habit-it became my way of teaching and thinking about teaching and it was because of those influences.

What inspired you during that visit of Jack Whitehead? I believe he inspired a number of people that were with him that summer.

The summer school course with Jack Whitehead was a two-week intensive and we met for four out of seven days for two weeks. We walked into the first class and nobody knew what they were getting into. It was a course on action research-that's all we were told. When we walked in there were a couple of first pages of articles on the table, and one of them was an article by Elliot Eisner, The Promise and Perils of Alternate Forms of Data Representation. And I thought, "Why, I just read that. This is going to be really good: we're going to be able to talk about something that l've just read."

Then Jack came in and all of a sudden we felt quite uncomfortable. He challenged us to write value claims - "What do you care about in education?" After I got to know him I realized what a kind and caring man he was, but when he came in he was all business-"Shall we begin?" So, we started by writing value claims. I'd never really thought about what I cared about in education, never thought about how I lived my values in my practice, or how I was accountable to my values. Everybody in the room was feeling the same, but nobody was sharing yet because many of us didn't know each other.

In the morning, there were brass bands practicing outside and huge trucks reeling by on the highway. We had all this turmoil going on and nobody felt comfortable. Then, in the afternoon it was strange. One of those huge summer thunderstorms struck outside, with the water blowing against the windows. We laughed and thought, "Oh my goodness, how are we going to survive two weeks?" We began self-studies and the experience was extremely intense. We had to provide evidence that we were living our values in our practice-tangible evidence like notes from parents, documents from school, or student artefacts. There were a few of us who created negative dialectics, finding evidence that we were not living our values in our practice. 
I came home on that first weekend. I had just packed up my classroom because I was coming back to university full time in the fall. I had boxes all over the house and I told my husband, "Go away, leave me alone, I'm working." I started going through stuff, sure I was never going to find anything to disprove my claim to value students above all else. Well, I found all kinds of evidence, and I was basically on my knees when I went back to Bishop's that Monday morning. I was just so shaken by things that I had in my possession that I'd never really read, that I'd never really looked at, and never really wanted to.

For example, there was a student, Mike, and in my class he was just great. I would ask him to try a strategy and he would try it until he perfected it. He was really on the path to being a good student going from a self-contained special ed. class into the mainstream. But outside of my classroom he wasn't doing so well. Socially, he was not really adjusting to high school. He was into all kinds of mischief. But I just thought, "Well, that's somebody else's problem, that's not my problem." He was in my class for two years. In grade nine, he left to go into the mainstream and he became a terrible bully, doing all kinds of horrible things to weaker students. This is what I confronted at summer school. I knew all of these things, but I stopped caring when kids left my classroom. They became somebody else's problem.

I made it through the second week of summer school and I really didn't know whether I'd ever return to teaching. I was at university studying full time and I thought, "Wow, what for?" I took a lot of time to sort out my thinking and what I concluded was that I had to switch my thesis topic and continue my self-study for my dissertation, to work out how I was going to live through my values outside my classroom. That became through teacher research and mentoring other teachers who wanted to engage in research. It was a huge transformation. It was a horribly painful transformation, but it certainly made a difference to me as a teacher and as a person altogether inside and outside of a classroom.

\section{Can you tell me how you and your "Narrative Inquiry Group" got started?}

The Narrative Inquiry Group ${ }^{1}$ began as an offshoot of an action-research project that I was facilitating in the high school from which I retired. I was invited by a teacher to come into the school to help her with an action-research project. She was going to be teaching, "Mathematics Resource, Secondary," and was a new teacher. I said, "Sure, I'll come in and work with you on two conditions: one, you have to get the blessing of the principal, and two, you have to open up the project to everybody in the school." 
The principal was happy to have me there. He called a meeting and 20 people showed up, interested in action research, including the principal, a vice-principal and her secretary, teachers, and support staff. That was the beginning of my volunteer work in the school. The narrative group grew out of this with a collection of English teachers who were really interested in storying. I introduced them to the work of Jean Clandinin and we started talking about "cover stories" and "inside stories." We got together to share stories, but we didn't start writing for quite a while. But then the need for it to be research surfaced in me, and so it became more than just sitting and talking and telling stories. We started looking at why we tell stories, what stories we tell, why they are important, what we learn from our own stories and from each other's stories. So it became more formalized over the years.

I started looking at narrative inquiry, not just telling stories and writing stories, but really getting into the meaning of the stories and getting to the learning that teachers do. I firmly believe that teachers have to learn all the way through. This notion that you go to school, get a B.Ed, know everything there is to know about teaching, and stop learning is quite ridiculous. So slowly, slowly I was introducing the idea that we could read research and that we could write research and we could be researchers. Now we all are firmly of the opinion that we are-we work it, we live it, we are teacher researchers. We used to meet every second Friday morning before class when everybody was in the same school. Over the years, different people have joined, a few have left, so we're not all English teachers now-we're English, drama, dance, art teachers.

Because we are in different schools, we meet once a month on a Saturday or Sunday for the better part of the day. We talk and we write, and then we share. We looked for different ways of making our learning explicit, and we came across literary métissagethe work of Anita Sinner, Carl Leggo, and Erika Hasebe-Ludt in particular. Their method is something that really works for us, because we all have our stories and we all have our writing, and we all write in different ways. Some write lists, some write poems, some write stories, and some write essays. Métissage gives us a way to bring our stories together as one, to not just make our learning explicit, but to really give us something that launches us into the next piece. Everybody writes on a theme and then we braid our pieces and come up with something new and startling-nobody knows what is going to come out of the braiding. Métissage gives us direction, more questions, more ideas, more writing, and so on we go.

I understood from my graduate years how important it is to publish. If we're going to be researchers, we've got to go through that last stage of putting it out there for the public to validate. So publishing has become the last big step, and as you know we 
published $^{2}$ in your journal, which was a big thrill for all of us. That's not one that we're all comfortable with yet, but it will come.

Do you have any particular project that you could give us a little more detail about and the learning that came out of it with one of the colleagues that you worked with?

The first project that the Narrative Group did together is all about learning. We were exploring métissage. We had been invited for a number of years to Concordia University to a one-day life-writing workshop with Anita Sinner, Carl Leggo, and Erika HasebeLudt. After the first workshop we went back to our meetings and decided that we were going to embark on this: we were going to do a braid. We had to come up with a topic and everybody was saying, "Where are we going to find the time for this? I have so much difficulty finding balance in my life already." Well, balance became our topic. There were seven of us involved in this project. Each of us wrote a balance piece. We got together to share bits and pieces, until finally we each had a polished piece. We met at one of the teacher's homes in a beautiful pastoral setting. Everybody was relaxed and happy. We tried to figure out how to actually go about braiding because there's no how-to book on métissage that we've been able to find. We decided that everyone would read their piece and we would listen for lines that kind of clicked with us, and then we would figure out how to put those lines together. We spent a day reading and pulling out lines. Each of the pieces on balance was really different: it was balance in personal life, balance between personal and professional, balance as a new mother, all kinds of different perspectives on balance. We came up with four poems, ${ }^{3}$ completely unrelated to anything that anybody had written previously. It was miraculous as far as we were concerned. They are beautiful poems. Everybody's voice is there. A reader who doesn't know us would get something from these pieces. That was a huge turning point for the group when we actually produced our first métissage.

\section{Over the years, what are some of the highlights you've had working on teacher research?}

My personal success in my classroom practice after I was introduced to action research, self-study, and Jack's idea of living theory was transformational. The success of my students was remarkable when they left the self-contained class and went into the mainstream because I was just teaching a different way. I had some kids for three years. They noticed the change, could see the difference in the way I was approaching teaching and learning. I introduced inquiry into their learning-it really became an inquiry practice, inside out. 
The action research projects that some of the teachers completed in the first school I worked in as a facilitator were really remarkable and some of them were published in LEARNing Landscapes. ${ }^{4}$ They did not just create something new, but they changed the way they think about teaching and learning. That's something that teachers have to do voluntarily-you can't say, "Okay, you have to change, you have to think critically about what you're doing." Teachers becoming teacher researchers have to go through a process of change and I was able to track the progress of the change.

I'm working with another little group now, "The Living Theory Project" and the question we're addressing is: "How can I live my values more fully in my practice?" We meet once a month on a Saturday and we basically talk. We don't produce anything together-it's all about ideas. And that for me is wonderful because I'm just participating in a conversation at that point; I'm not chasing around looking for articles or ideas, or recommending books. It's just professional conversation-for me that's a highlight, because there's been a shift in my role, in my perspective within the groups.

I guess the most recent highlight is my work as a consultant in a First Nations school. I was asked to do workshops, and I said, "I don't do workshops. I never really appreciated them as a teacher and I really just can't take your money, but I will write a proposal for an alternative." So what I proposed was that I would be in the school for two days a week and I would work with a small group of teachers, teaching them something about the process of doing research on practice. They could pick their own problem and we'd find a solution together, rather than having me come in and do a cooperative learning workshop or a behaviour management workshop, or whatever. My time in the school just wrapped up and there are some beautiful projects that are in place now. We're going to have a Sharing Circle in June. Each teacher will share a project with colleagues, and next year mentor one of them as they begin the process. So that's definitely a highlight.

Can you say a little bit about how you transitioned from being the facilitator at the group to being a member of the group?

It's something that I have struggled with and when I stopped struggling, it started to happen. I had this feeling that everything was going to derail if I wasn't in control, and it didn't happen that way. I still do subversive things from time to time. I'll say, "Oh, I just read a really great book. You have to read this." 
Sometimes I've had to kind of push people to take the lead. I was invited to lead professional conversations in a school, conversations about whatever problem anybody brought to the table at lunchtime on Fridays. There is a big transition going on in the school right now, and they're changing the whole program. The conversations became very specific to that, and there was a very significant and remarkable absence of trust amongst the teachers involved in these conversations.

I brought in some ideas from business on team building. I made sure that key teachers were comfortable with the idea, and that they could take on the role of implementing a team-building model. It was working, but the first step is to establish trust, and once you've established trust you can get into conflicts, conversations about things that you don't agree about, with the idea that you're going to achieve consensus. Then you can get into "buy-in" and "results." It became clear to me that I couldn't continue to participate because I couldn't be trusted. I'm an outsider. So, two of the teachers took on the facilitator's role.

Sometimes transitioning is forced and sometimes it's something that happens quite naturally, which is more of the case of what happened with The Narrative Inquiry Group. We don't need a leader; they don't need me to be there-I want to be there, but the group functions quite happily on its own. Everybody has their own expertise, their own gifts, their own strengths, and there's respect—I think that's maybe the key thing: respecting each other's intelligences, talents, spaces, and needs.

What do you suggest to other teachers who want to get involved in researching their own practice?

I actually believe it begins before teachers are credentialed. I think the responsibility for the shift to an inquiry perspective belongs here at the university-that's where it has to start. Actually, maybe it can go back further than that. I think if kids go through school and are introduced to an inquiry curriculum, then they're going to start thinking differently: they'll develop the mind-set for being curious and looking at problems before problems find them. But I really do believe that it starts here and that it should be embedded in not just one course, but throughout the program for pre-service teachers.

To introduce teacher research to a school is not easy. I know that when I started working at a school last fall, there were questions about what teacher research was going to do for them and where were they going to find the time. It was just kind of slow and steady. I was working basically as a research assistant. A teacher would say, 
"There is a problem with engagement in this classroom" and I would say, "I'll bring in some ideas that we can look at"-kind of like Jack with his first pages of articles on the table.

The first thing the school needs is a commitment from a core of teachers, who would be committed to the idea and the administration would definitely have to be committed to the idea. But how do you get that commitment? There has to be a need, a recognized need for change.

I'm sad when, sometimes in schools, I see people who are content with complaining and inertia. They don't really, when it comes down to it, want change. There's a culture of unhappiness, and that has to change to a culture of care. Once you have commitment, there has to be trust, particularly in an endeavour that involves the threat of losing something that's safe-even if that something is not good. The threat of change can be really disturbing. There has to be that trust amongst the people who are committing to a teacher research perspective. It doesn't take long once you've made the commitment and learned to trust, and once you've started the process you can't stop. It just becomes a way of being in the classroom, in the school. You can't say, "Well, I'm not going to do that this year." That just doesn't work.

\section{Notes}

1. The Narrative Inquiry Group is a writers' collective with 11 members. The group is composed of teachers and non-teaching professionals, active and retired, from three public secondary schools in Quebec, Canada. It meets every few weeks to talk, reflect, write, analyze, illustrate, and braid lived experience. As well, the group seeks opportunities to perform the products of our professional conversations and to engage with others in the practice of narrative inquiry and literary métissage.

2. "To Where Teachers Learn: Following the Yellow Brick Road" appeared in the Autumn 2014 edition issue of the journal and was written by The Narrative Inquiry Group.

3. To read these poems, please visit: http://www.learnquebec.ca/en/content/learning landscapes/Documents/LL_no16_poeme.pdf

4. "Teacher Inquiry for Educational Change" appeared in the Spring 2011 edition issue of the journal and was written by Danielle Couture, Judith McBride, Sujata Saha, Denise Schellhase, and Kelly Von Eschen. 


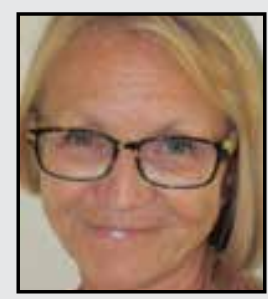

Judith McBride, $\mathrm{PhD}$, is a retired special education teacher of the Riverside School Board, and former sessional lecturer in the Faculty of Education of McGill University. She is a Hilroy Fellow, and has been recognized for academic excellence by the Canadian Psychological Association. Judith has volunteered with teacher researchers in Canada and abroad, and is currently working as a consultant developing teacher inquiry projects in various contexts. Her research interests include action research, narrative inquiry, instructional design, and teacher learning through self-study.

\section{LINK TO:}

https://ca.linkedin.com/pub/judy-mcbride/27/990/526 